\title{
The effects of solid and vapour phase compositional variations on the amphibolite facies to granulite facies transition in the Agto metadolerites
}

\author{
William Glassley and Kai Serrensen
}

Metadolerites occurring in the vicinity of Agto (within the Isortôq Complex of central West Greenland) have been metamorphosed in upper amphibolite to garnet granulite facies. Detailed sampling and petrographic study of these demonstrates that the entire sequence of assemblages may occur in individual dykes, with the amphibolite assemblages normally restricted to dyke margins, garnet granulite facies rocks occurring in the dyke cores, and pyroxene granulite facies rocks intervening between these two. Bulk rock chemical analyses demonstrate that the dykes are chemically homogeneous with respect to all oxides except $\mathrm{Al}_{2} \mathrm{O}_{3}$ and $\mathrm{Na}_{2} \mathrm{O}$. Nevertheless, variation in the latter two oxides is small, and demonstrably is not a parameter which significantly controls assemblage development. Modal abundance patterns suggest that two reactions are responsible for the assemblage progression we observe:

(1) Amphibole $+\mathrm{Q} \gtrless$ Plagioclase + Clinopyroxene + Orthopyroxene $+\mathrm{H}_{2} \mathrm{O}$

(2) Amphibole + Anorthite + Orthopyroxene $\gtrless$ Garnet + Clinopyroxene + Albite + $\mathrm{H}_{2} \mathrm{O}$.

Electron microprobe analysis of all coexisting phases demonstrates that the progression from amphibolite facies assemblages to pyroxene granulite facies assemblages results in the extraction of edenite and tschermakite components from the amphibole in approximately a 2:1 ratio, to generate clinopyroxene, orthopyroxene and plagioclase. Garnet granulite assemblages are generated by the further reaction of these amphibole components with orthopyroxene to generate clinopyroxene, garnet and plagioclase.

The algebraic removal of small but systematic compositional variations within the dykes allows derivation of six equilibria (Table 1), which provide a general model for metamorphism of basaltic rocks under high grade metamorphic conditions (fig. 1). This model takes the form of the idealized assemblage sequences which will develop along (regional) gradients in $\mathbf{X}_{\mathbf{H}_{2} \mathbf{O}}$, temperature and/or solid pressure. Analysis of these equilibria demonstrates that variable silica activity and $\mathrm{Fe}^{2+}-\mathrm{Mg}^{2+}$ exchange will modify reaction stoichiometry, will affect the ratio of edenite to tschermakite in amphibole breakdown reactions, and will modify the composition of the product plagioclase. These variations together with variations in water fugacity will locally modify the ideal assemblage sequences, and will explain the complex assemblage relationships observed in metabasic rocks of natural high grade terrains. 
Table 1. Equilibria in the pure-Mg system

\begin{tabular}{ccl}
\hline $\begin{array}{l}\text { Reaction } \\
\text { Number }\end{array}$ & Absent & Reaction \\
\hline 4 & $\mathrm{En}$ & $8 \mathrm{Ed}+4 \mathrm{Ts}+19 \mathrm{Q}+1 \mathrm{An}=8 \mathrm{Ab}+25 \mathrm{Di}+9 \mathrm{Py}+12 \mathrm{H}_{2} \mathrm{O}$ \\
5 & $\mathrm{An}$ & $2 \mathrm{Ed}+1 \mathrm{Ts}+5 \mathrm{Q}=2 \mathrm{Ab}+6 \mathrm{Di}+1 \mathrm{En}+2 \mathrm{PY}+3 \mathrm{H}_{2} \mathrm{O}$ \\
6 & $\mathrm{Ab}, \mathrm{Ed}, \mathrm{Ts}, \mathrm{V}$ & $4 \mathrm{En}+1 \mathrm{An}=1 \mathrm{Di}+1 \mathrm{Py}+1 \mathrm{Q}$ \\
7 & $\mathrm{Di}$ & $2 \mathrm{Ed}+1 \mathrm{Ts}+11 \mathrm{Q}+4 \mathrm{Py}=2 \mathrm{Ab}+6 \mathrm{An}+25 \mathrm{En}+3 \mathrm{H}_{2} \mathrm{O}$ \\
8 & $\mathrm{Py}$ & $2 \mathrm{Ed}+1 \mathrm{Ts}+7 \mathrm{Q}=2 \mathrm{Ab}+2 \mathrm{An}+4 \mathrm{Di}+9 \mathrm{En}+3 \mathrm{H}_{2} \mathrm{O}$ \\
9 & $\mathrm{Q}$ & $2 \mathrm{Ed}+1 \mathrm{Ts}+5 \mathrm{An}+19 \mathrm{En}=7 \mathrm{Py}+11 \mathrm{Di}+2 \mathrm{Ab}+3 \mathrm{H}_{2} \mathrm{O}$ \\
\hline
\end{tabular}

$\mathrm{Ab}=$ albite $\left(\mathrm{NaAlSi}_{3} \mathrm{O}_{8}\right), \mathrm{An}=$ anorthite $\left(\mathrm{CaAl}_{2} \mathrm{Si}_{2} \mathrm{O}_{8}\right)$, Di $=$ diopside $\left(\mathrm{CaMgSi} \mathrm{O}_{6}\right)$, $\mathrm{Ed}=$ edenite $\left(\mathrm{NaCa}_{2} \mathrm{Mg}_{5} \mathrm{AlSi}_{7}(\mathrm{OH})_{2}\right)$, En = enstatite $\left(\mathrm{MgSiO}_{3}\right)$, Py = pyrope $\left(\mathrm{Mg}_{3} \mathrm{Al}_{2} \mathrm{Si}_{3} \mathrm{O}_{12}\right), Q=$ quartz $\left(\mathrm{SiO}_{2}\right), \mathrm{Ts}=$ tschermakite $\left(\mathrm{Ca}_{2} \mathrm{Mg}_{3} \mathrm{AI}_{4} \mathrm{Si}_{6} \mathrm{O}_{22}(\mathrm{OH})_{2}\right)$. $\mathrm{V}=\operatorname{vapour}\left(\mathrm{H}_{2} \mathrm{O}\right)$.

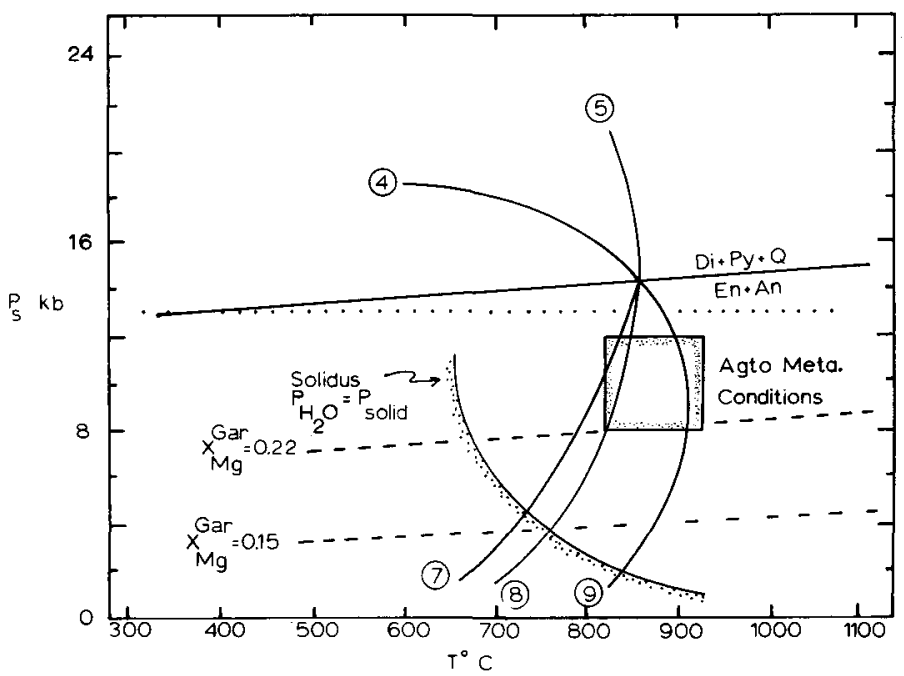

Fig. 1. $P-T$ diagram indicating the experimentally determined location for reaction (6) (Hensen, 1976). The other equilibria in Table 1 are located such that they pass through the $P-T$ conditions deduced for the Agto region (boxed area). The solidus for amphiboles and basalts $\left(\boldsymbol{P}_{\mathrm{H}_{2} \mathrm{O}}=\boldsymbol{P}_{\text {ToraL }}\right)$ is constructed from the data of Yoder \& Tilley (1962), Lambert \& Wyllie (1970) and Helz (1973). Also indicated are the calculated locations of reaction (6), determined from the compositional parameters obtained in this study and presented in Table 1 . Shown schematically is the location of the $T-X_{\mathrm{H}_{2}} \mathrm{O}$ section (fig. 2). 
Fig. 2. Schematic $\mathrm{T}-\mathbf{X}_{\mathrm{H}_{2} \mathrm{O}}$ diagram, indicating the relative positions of the equilibria in Table 1. The arrows represent progressive metamorphic pathways experienced by the driest core rocks (pathway I), and by the wetter adjacent rocks. Pathways II and III result in orthopyroxene-bearing, garnet-absent assemblages, while pathway IV is for pyroxene-absent assemblages.

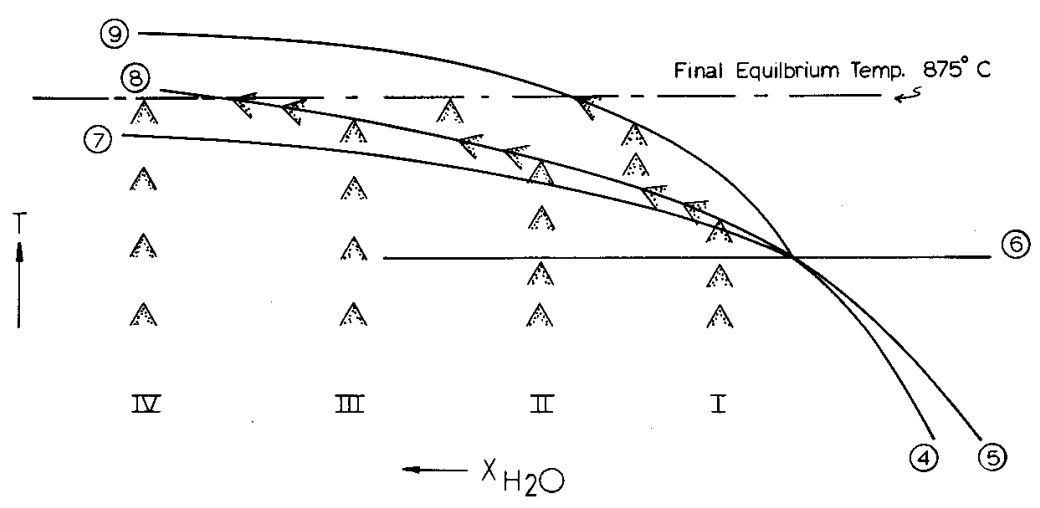

The derived equilibria, when placed in $\mathrm{T}-\mathrm{X}_{\mathrm{H}_{2} \mathrm{O}} \mathrm{O}$ space, allow description of the metamorphic history of the Agto metadolerites. To attain the final conditions indicated (fig. 2) requires that the garnet-bearing assemblages coexist with an $\mathrm{H}_{2} \mathrm{O}$-depleted (drier) fluid phase than that present along the dyke margins. Progressive metamorphic pathways that would lead to these final conditions are indicated in the figure.

Final equilibration temperatures, calculated from ten coexisting clinopyroxene-orthopyroxene pairs, is $875^{\circ} \mathrm{C} \pm 40^{\circ} \mathrm{C}$. Equilibration pressures are calculated to be $8 \mathrm{~kb} \pm 4$ $\mathbf{k b}$, from four orthopyroxene-garnet pairs. The temperatures and pressures thus calculated require that $P_{\mathrm{H}_{2} \mathrm{O}} \ll 0.5 P_{\text {solid. }}$

\section{References}

Heltz, R. T. 1973: Phase relations of basalts in their melting range at $P_{\mathrm{H}_{2} \mathrm{O}}=5 \mathrm{~kb}$ as a function of oxygen fugacity. Part I. Mafic phases. J. Petrol. 14, 249-302.

Hensen, B. J. 1976: The stability of pyrope-grossular garnet with excess silica. Contrib. Mineral Petrol. 55, 279-292.

Lambert, I. B. \& Wyllie, P. J. 1970: Low velocity zone of the earth's mantle: incipient melting caused by water. Science $169,764-766$.

Yoder, H. S. \& Tilley, C. E. 1962: Origin of basalt magmas: an experimental study of natural and synthetic rock systems. J. Petrol. 3, 342-532.

W.G.,

Department of Geology,

Middlebury College,

Middlebury,

Vermont 05753,

USA.
K.S.,

Geologisk Institut, Aarhus Universitet, DK-8000 Árhus C, Denmark. 